\title{
A POTENTIAL STUDY ON CLOVE OIL, EUGENOL AND EUGENYL ACETATE AS DIESEL FUEL BIO-ADDITIVES AND THEIR PERFORMANCE ON ONE CYLINDER ENGINE
}

\author{
Asep Kadarohman ${ }^{1}$, Hernani $^{2}$, Fitri Khoerunisa ${ }^{3}$, Rizki Maryam Astuti ${ }^{4}$ \\ Dept of Chemistry Education, Indonesia University of Education, \\ Jl. Dr. Setiabudhi No 229, Bandung, Indonesia \\ E-mails: ${ }^{1}$ kadar@upi.edu; ${ }^{2 h e r n a n i @ u p i . e d u ; ~}{ }^{3}$ itri_khoerunnisa@yahoo.com; ${ }^{4}$ rizki139@yahoo.com
}

Received 26 February 2009; accepted 1 February 2010

\begin{abstract}
Research on the potency of essential oils as diesel fuel bio-additives has been reported. It also has been found out that clove oil has a better performance than turpentine oil on decreasing Break Specific Fuel Consumption (BSFC) and reduces the exhaust emissions of the engine. Clove oil is essential oil the content of which is made of eugenol acting as the main component. Eugenol has a bulky structure, two oxygen atoms and can form eugenyl acetate from ester reaction. Eugenyl acetate has a bulkier structure and higher oxygen content than eugenol which leads to optimizing the process of fuel combustion. This experiment can give information about the potency of the bio-additive based on clove oil and eugenol and about the influence of oxygen enrichment with eugenol on the performance of the diesel fuel bio-additive. In general, this experiment covered three stages. The first step is the characterization of the diesel fuel bio-additive using a GCMS and FTIR spectrophotometer. The second step is the characterization of the diesel fuel bio-additive and composition optimization. The final step is conducting a diesel fuel bio-additive performance test on one cylinder engine on a laboratory scale. The results of the carried out experiment show that clove oil, eugenol and eugenyl acetate can decrease Break Specific Fuel Consumption (BSFC) and reduce the exhaust emissions of the engine as well as oxygen enrichment can help in reaching optimal fuel combustion.
\end{abstract}

Keywords: clove oil, eugenol, eugenyl acetate, diesel fuel, bio-additive, engine.

\section{Introduction}

A number of researches on an increase in diesel fuel quality have been conducted. Gupta et. al (2007) studied the effect of Di-tertiary Butyl Peroxide (DTBP) on Primary Reference Fuels (PRFs) in Homogeneous Charge Compression Ignition (HCCI) engines and the results of the performed experiment show that a DTBP predominant mode of action on low Octane Number $(\mathrm{ON})$ fuels is thermal while for high ON fuels it is chemical. Shih (1998) examined the influence of fuel additives such as EHN, DTBP, MTBE, DMC, diglyme, monoglyme and ethanol on the exhaust emissions of the diesel engine. The overall results of the carried out experiment show that fuel additives have a substantial effect on the engine's fuel spray penetration, fuel-air mixing processes, ignition delay, chemical reaction rates, total heat release and have a positive impact on reducing exhaust emissions; however, it is not necessary that these effects are all positive and significant on every type of emissions (temperature, $\mathrm{NO}_{\mathrm{x}}, \mathrm{HC}$ and smoke). Johnson (2008) analyzed the oxidation behavior of SI primary reference fuels with propionaldehyde and DTBP as an additive. The conducted experiment shows an addition of propionaldehyde or a negative temperature coefficient (NTC) of DTBP effects during HCCI combustion. Research into the quality of fuels and their biocomponents also presented by another researchers, for example: Al-Hasan and Al-Momany (2008); Butkus et al. (2007); Chen et al. (2008); Kwanchareon et al. (2007); Lebedevas and Lebedeva (2009); Lebedevas et al. (2009); Lebedevas et al. (2007); Lingaitis and Pukalskas (2008a, 2008b); Matijošius and Sokolovskij (2009); Mittelbach and Remschmidt (2004); Pukalskas et al. (2009); Raslavičius and Bazaras (2009); Raslavičius and Markšaitis (2007); Shi et al. (2006); Török (2009); Yao et al. (2008).

Fuel oxygen content (oxygenates) is one of parameters for determining the quality of diesel fuel. Song et al. (2002) has considered that blending oxygen-containing compounds with diesel fuel leads to an increase in cetane number and the process of fuel combustion can be completed. It is in accord with research published by Kadarohman et al. (2008) at the International Seminar on Chemistry who reported that a clove oil bio-additive 
had a better performance than turpentine oil to increase the process of fuel combustion reactivity.

The detailed mechanisms of the oxygenated fuels reducing the exhaust emissions of the engine are not properly understood. Mueller and Martin's (2002) experiment has shown that the overall oxygen content is not the only important parameter in determining the potential of reduction in exhaust emissions of the oxygenated fuel.

Clove oil is the essential oil containing eugenol as the main component. Eugenol allows splash blending in a solution possibly used for the first time. Analysis shows that eugenol has two oxygen atoms (Kadarohman 2003). The oxygenated molecular structure also plays a significant role. The bulky structure of eugenol can decrease the strength of Van der Walls bond in diesel fuel and the chain of carbon. Oxygen content and the molecular structure can lead to an increase in the efficiency of the fuel combustion process. The structure of eugenol is displayed in Fig. 1.<smiles>C=CCc1ccc(O)c(O)c1</smiles>

Fig. 1. The structure of eugenol<smiles>C=C(C)Cc1ccc(O)c(OC)c1</smiles>

Fig. 2. The ester reaction of eugenol forms eugenyl acetate

Eugenol can form eugenyl acetate from ester reaction. Eugenyl acetate has a bulkier structure and higher oxygen content than eugenol. Such enrichment with oxygen can optimize the process of fuel combustion. The caused reaction is presented in Fig. 2.

\section{Methods of Research}

The experiment included three stages:

\section{Diesel fuel and bio-additive characterization.}

At this stage, diesel fuel, clove oil, eugenol and eugenyl acetate were characterized using a FTIR and GCMS spectrophotometer.

\section{The physical characterization and composition of bio-additive fuel blends were optimized.}

According of Callahan et al. (1987), the quality parameter of diesel fuel is influenced by specific gravity, viscosity, aniline point and diesel index, and therefore this experiment covered physical characterization ob- tained by specific gravity parameter, viscosity, aniline point, flash point, API gravity and diesel index. The received data was compared with diesel fuel specifications for DIRJEN MIGAS. An optimum composition was determined by a test on fuel consumption flow in one cylinder engine (using KUBOTA engine).

\section{Performance test in one cylinder engine.}

Performance test was done on a laboratory scale using one cylinder engine HATZ 667 cc 1D81Z with testing parameters for fuel consumption flow and exhaust emissions.

\section{Results}

\subsection{Diesel Fuel and Bio-additive Characterization}

First, the characterization of diesel fuel, clove oil, eugenol, and eugenyl acetate was done using the GCMS and FTIR spectrophotometer.

\section{a. Diesel Fuel Characterization}

GC analysis of diesel fuel has shown that diesel fuel used in this experiment contains 66 alkane compounds with the number of carbon which is about 14-19 (Fig. 3). Based on the MS analysis of the reached peaks, some compounds of diesel fuel can be identified (Table 1).

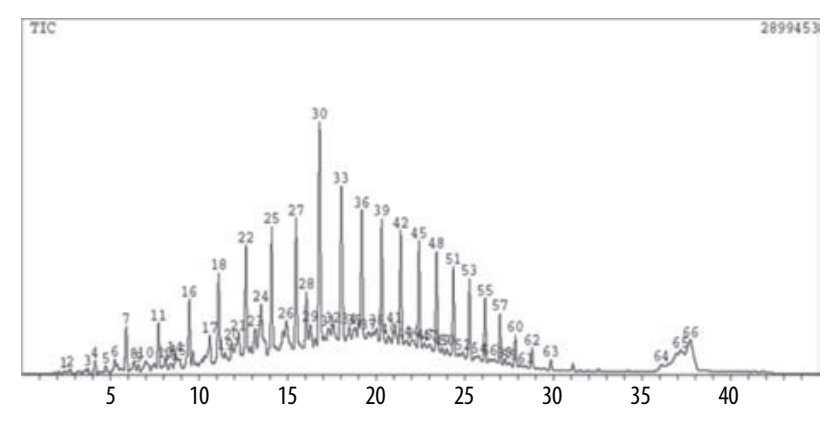

Fig. 3. GC spectra of diesel fuel

Table 1. Some compounds of diesel fuel.

\begin{tabular}{ccccc}
\hline No & $\begin{array}{c}\text { Molecular } \\
\text { Formula }\end{array}$ & Name & $\begin{array}{c}\text { Retention } \\
\text { time } \\
\text { (minutes) }\end{array}$ & $\begin{array}{c}\text { Conc. } \\
(\%)\end{array}$ \\
\hline 1 & $\mathrm{C}_{14} \mathrm{H}_{30}$ & Tetradekane & 14.278 & 3.60 \\
\hline 2 & $\mathrm{C}_{15} \mathrm{H}_{32}$ & Pentadekane & 16.071 & 4.18 \\
\hline 3 & $\mathrm{C}_{16} \mathrm{H}_{34}$ & Heksadekane & 17.770 & 4.67 \\
\hline 4 & $\mathrm{C}_{17} \mathrm{H}_{36}$ & Heptadekane & 19.428 & 9.28 \\
\hline 5 & $\mathrm{C}_{18} \mathrm{H}_{38}$ & Oktadekane & 20.925 & 6.95 \\
\hline 6 & $\mathrm{C}_{19} \mathrm{H}_{40}$ & Nonadekane & 22.363 & 5.03 \\
\hline
\end{tabular}

\section{b. Clove Oil Characterization}

This experiment used clove oil taken from MITRA PALA MAS, Kampung Krajan Wanayasa, Purwakarta. Clove oil was characterized using the GCMS and IR spectrophotometer to know the content of compounds in clove oil. GC and IR spectra of clove oil are shown in Figs 4 and 5 respectively. 


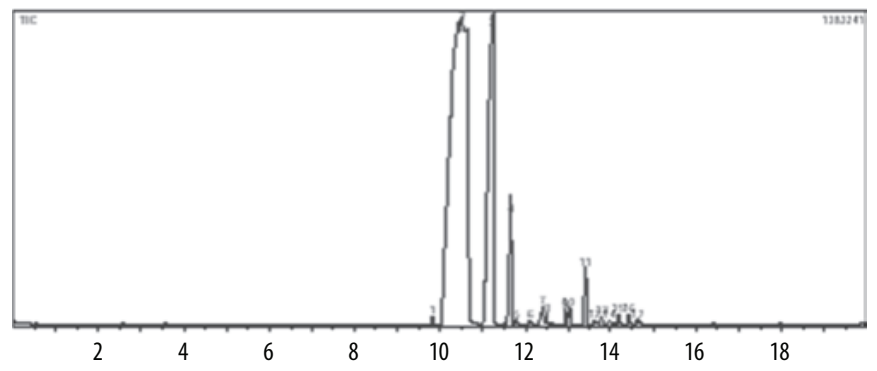

Fig. 4. GC spectra of clove oil

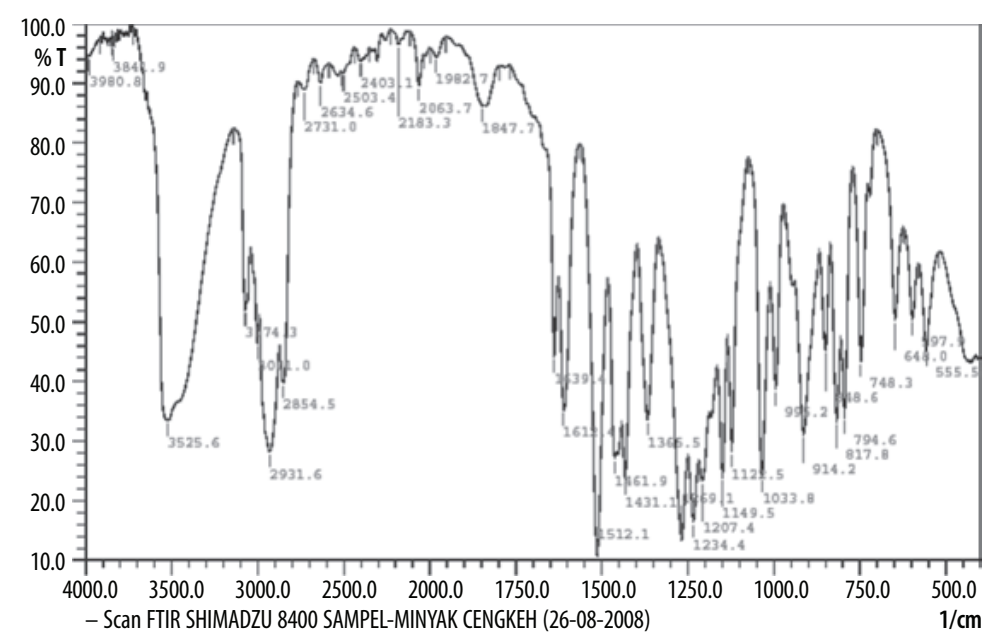

Fig. 5. IR spectra of clove oil

The chromatogram in Fig. 4 shows there are two peaks having high concentration. They are the second and third peaks making $70.54 \%$ and $21.54 \%$ respectively. The second peak has the retention time of 10.515 minutes while the third peak has that of 11.223 minutes. Both peaks were analyzed using MS and the results of the carried out analysis are shown in Figs 6 and 7.

On the basis of the MS database, these peaks can be identified. The first peak is eugenol, whereas the second one is cariofilena.

\section{c. Eugenol Characterization}

Eugenol used in this experiment came from PT. Indesso Aroma Cilengsi Bogor. The chromatogram of GC analysis on eugenol shows there is one peak with $100 \%$ concentration at the retention time of 10.552 minutes (Fig. 8).

MS analysis of the peak displayed in Fig. 9 and IR analysis in Fig. 10 show that the peak is eugenol which means it is of $100 \%$ purity.

\section{d. Eugenyl Acetate Characterization}

Eugenyl acetate used in the experiment was taken from PT. Indesso Aroma Cilengsi Bogor. GC and IR analysis on this raw material is shown in Figs 11 and 12 respectively.

Two peaks within GC spectra are displayed in Fig. 11. The first peak has a concentration of about $0.59 \%$ with the retention time of 10.064 minutes and the second peak has a concentration of about $99.412 \%$

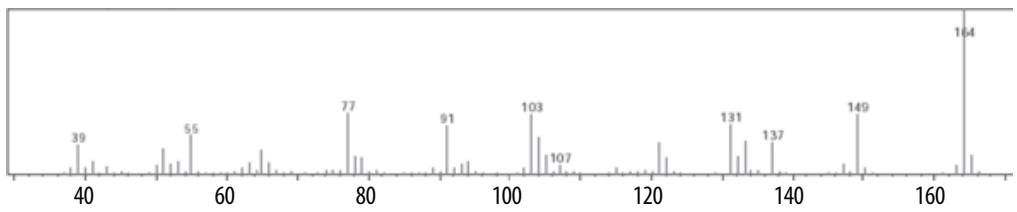

Fig. 6. MS spectra of the second peak

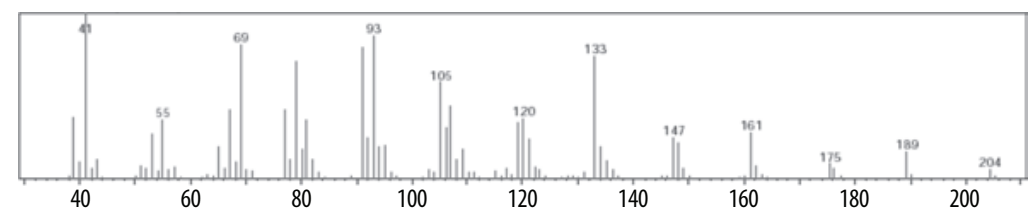

Fig. 7. MS spectra of the third peak 


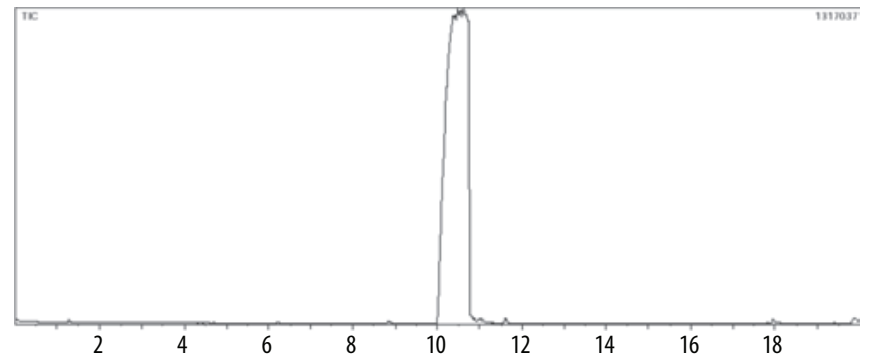

Fig. 8. GC spectra of eugenol

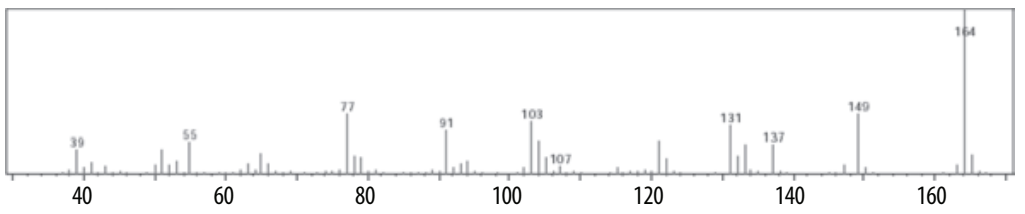

Fig. 9. MS spectra of the first peak

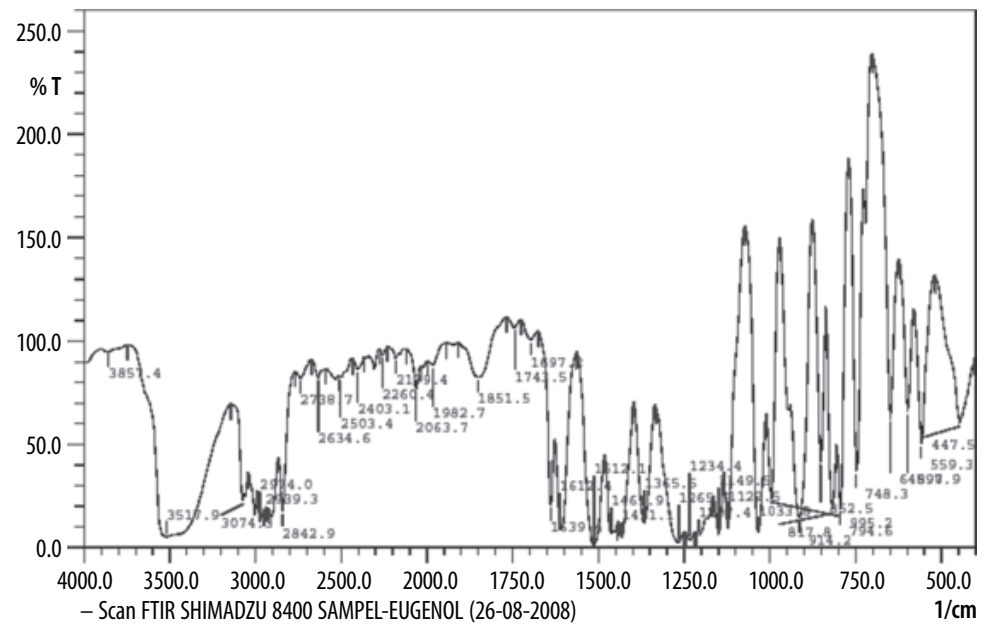

Fig. 10. IR spectra of eugenol

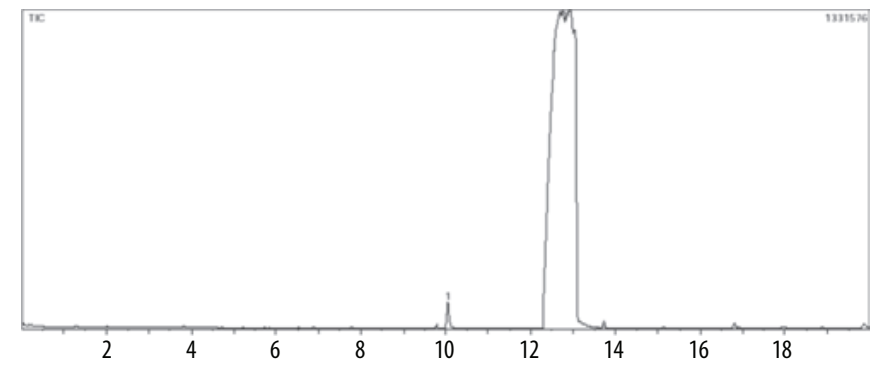

Fig. 11. GC spectra of eugenyl acetate

with the retention time of 21.816 minutes. Based on MS analysis (Figs 13 and 14), the identified peaks are eugenol and eugenyl acetate respectively.

\subsection{Physical Characterization and Composition Optimization of Bio-additive Fuel Blends}

\section{a. Clove Oil Fuel Blends}

The optimization of clove oil fuel blends was determined by the fuel consumption flow rate.

Fig. 15 shows that the optimum composition of clove oil is $0.6 \%$ and the fuel consumption rate is $251.91 \mathrm{~mL} /$ hour.

In $0.6 \%$ reformulation of clove oil, diesel fuel has the following physical characteristics which displayed in Table 2.

A comparison of these physical characteristics with DIRJEN MIGAS specification shows that the physical characteristics of clove oil fuel blends still complied with diesel fuel specifications for DIRJEN MIGAS which means that the essential oil is safe to be used as a bio-additive. 


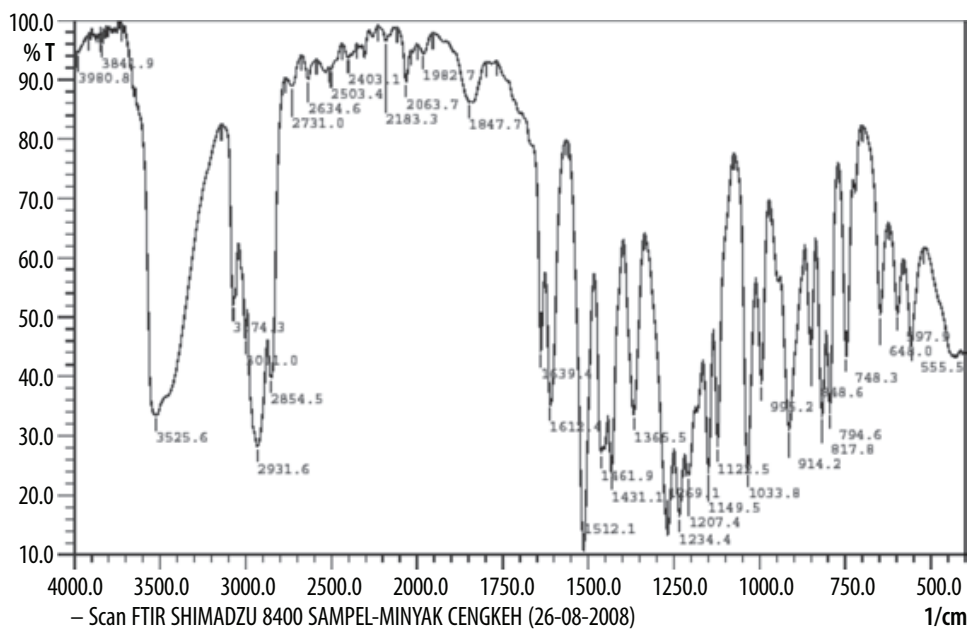

Fig. 12. IR spectra of eugenyl acetate

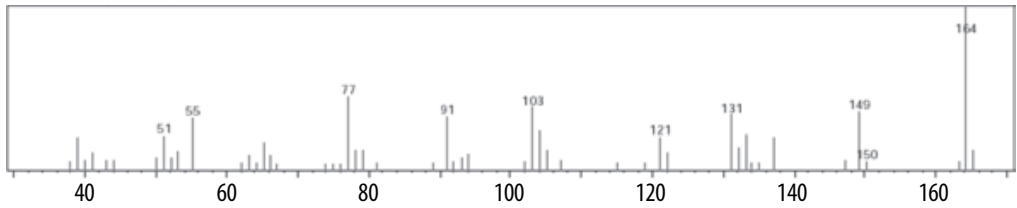

Fig. 13. MS spectra of the first peak

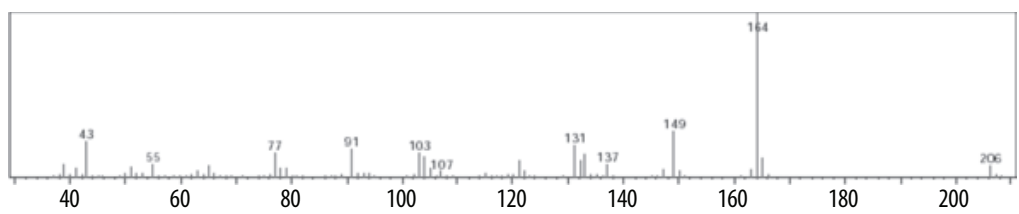

Fig. 14. MS spectra of the second peak

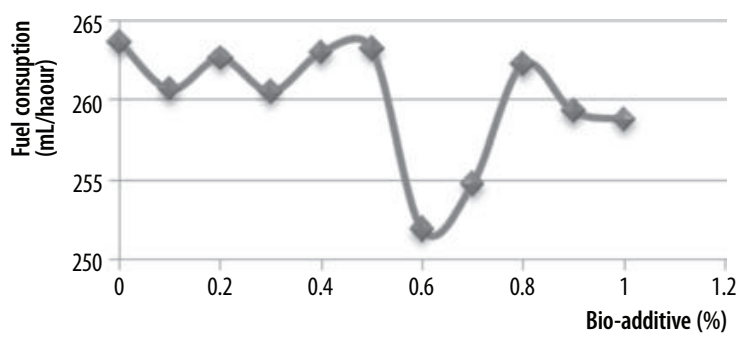

Fig. 15. The influence of clove oil fuel blends on the fuel consumption flow rate

Table 2. Physical characteristics of diesel fuel and diesel fuel $+0.6 \%$ clove oil

\begin{tabular}{lcccc}
\hline \multirow{2}{*}{ Parameters } & Diesel fuel & Diesel fuel $+0.6 \%$ clove oil & \multicolumn{2}{c}{ DIRJEN MIGAS specification } \\
\cline { 3 - 5 } & & & Min & Max \\
\hline Fuel consumption $(\mathrm{mL} /$ hour $)$ & 263.58 & 251.91 & - & - \\
\hline Specific gravity at $25^{\circ} \mathrm{C}(\mathrm{g} / \mathrm{mL})$ & 0.8452 & 0.8473 & - & 0.82 \\
\hline Specific gravity at $15.6^{\circ} \mathrm{C}(\mathrm{g} / \mathrm{mL})$ & 0.8522 & 0.8536 & - & - \\
\hline API gravity & 34.5408 & 34.2685 & 129.6 & - \\
\hline Aniline point $\left({ }^{\circ} \mathrm{F}\right)$ & 156.2 & 149.9 & - & - \\
\hline Diesel index & 53.9527 & 51.3685 & 1.6 & 5.8 \\
\hline Viscosity $(\mathrm{cSt})$ & 3.7215 & 3.6718 & 60 & - \\
\hline Flash point $\left({ }^{\circ} \mathrm{C}\right)$ & 73 & 72 &
\end{tabular}




\section{b. Eugenol Fuel Blends}

The influence of eugenol fuel blends on the fuel consumption flow rate is presented in Fig. 16.

A chart in Fig. 16 shows that the optimum number is $0.2 \%$ for eugenol having fuel consumption rate $252.21 \mathrm{~mL} /$ hour. The physical characteristics of this composition are displayed in Table 3.

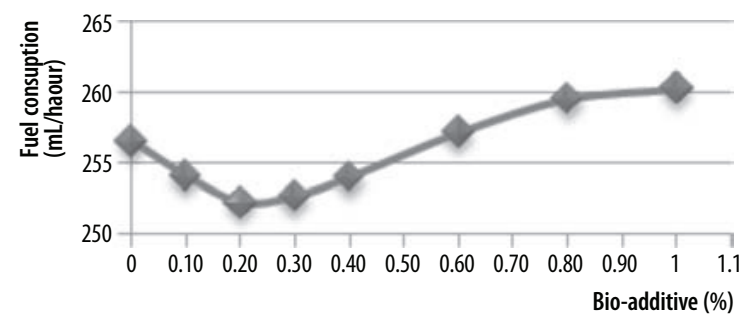

Fig 16. The influence of eugenol fuel blends on the fuel consumption flow rate

Physical parameters for the blends of $0.2 \%$ eugenol are still in the upper minimum limit of DIRJEN MIGAS specification.

\section{c. Eugenyl Acetate Fuel Blends}

An addition of eugenyl acetate considers the composition of eugenol fuel blends $(0.2 \%)$. The process is caused by eugenyl acetate which is a product of oxygen enrichment with eugenol producing ester reaction. It offers the possibility of oxygen enrichment that can optimize the fuel combustion process.

An addition of eugenyl acetate to diesel fuel must be similar to the composition of eugenol fuel blends in order to identify the effectiveness of oxygen enrichment with bio-additive blends.

\subsection{Bio-additive Fuel Blends Performance Test on One Cylinder Diesel Engine}

The performance test was investigated using one cylinder engine HATZ 667 cc 1D81Z with speed torque and weight variation.

The performance test covered the experiment with clove oil, eugenol and eugenyl acetate in $0.2 \%$ composition respectively. The use of clove oil was different from the experiment results of the optimized composition.
It considers a eugenol addition because it is the main component of clove oil. The performance of all bio-additives can be compared in the same composition. The performance of bio-additives was shown applying BSFC (Break Specific Fuel Consumption) parameter. Good performance has a low number of BSFC the bio-additives of which are shown in the below Fig. 17.

At $1500 \mathrm{rpm}, 2000 \mathrm{rpm}$ and $2500 \mathrm{rpm}$, diesel fuel and fuel blends with bio-additives have quite the same BSFC. However, at the high speed of $3000 \mathrm{rpm}$, all bioadditives have lower BSFC than unreformulated diesel fuel which means that all bio-additives can increase engine performance by increasing fuel combustion reactivity, especially eugenyl acetate, because eugenyl acetate has the lowest BSFC. Volumetric efficiency can show the effectiveness of the fuel combustion process.

The highest volumetric efficiency was achieved using eugenyl acetate at $3000 \mathrm{rpm}$ which proves that the bulky structure and content of oxygen atoms in eugenyl acetate lead to an increase in combustion reactivity with supplying oxygen internally (Fig. 18).

\subsection{Exhaust Emissions}

\section{a. $\mathrm{CO}$ and $\mathrm{CO}_{2}$}

In general, all bio-additives can decrease $\mathrm{CO}$ emission rate at various speeds and variation in weight. Containing high oxygen atoms in the bio-additives leads to the next oxidizing reaction of $\mathrm{CO}$ to form $\mathrm{CO}_{2}$. Nevertheless, a decrease in $\mathrm{CO}$ emission and consequently $\mathrm{CO}_{2}$ emission is going to increase. In this case, the reaction is as follows:

$$
\begin{aligned}
& 2 \mathrm{C}+\mathrm{O}_{2} \rightarrow 2 \mathrm{CO} ; \\
& 2 \mathrm{CO}+\mathrm{O}_{2} \rightarrow 2 \mathrm{CO}_{2} .
\end{aligned}
$$

A decrease in $\mathrm{CO}$ concentration is shown in Fig. 19. An increase in $\mathrm{CO}_{2}$ is presented in Fig. 20.

\section{b. Hydrocarbon (HC)}

HC emission is unburned fuel. The Fig. 21 show that each bio-additive has optimum performance to decrease $\mathrm{HC}$ concentration in exhaust emissions. However, at the high speed of $3000 \mathrm{rpm}$, reformulating diesel fuel using eugenyl acetate reaches the lowest hydrocarbon emission rate.

Table 3. Physical characteristics of diesel fuel and diesel fuel $+0.2 \%$ clove oil

\begin{tabular}{lcccc}
\hline \multirow{2}{*}{ Parameters } & Diesel fuel & Diesel fuel $+0.2 \%$ eugenol & \multicolumn{2}{c}{ DIRJEN MIGAS Specification } \\
\cline { 3 - 5 } & & & Min & Max \\
\hline Fuel consumption $(\mathrm{mL} /$ hour$)$ & 263.58 & 252.21 & - & - \\
\hline Specific gravity at $25^{\circ} \mathrm{C}(\mathrm{g} / \mathrm{mL})$ & 0.8452 & 0.83929 & - & 0.82 \\
\hline Specific gravity at $15.6^{\circ} \mathrm{C}(\mathrm{g} / \mathrm{mL})$ & 0.8522 & 0.83931 & - & - \\
\hline API gravity & 34.5408 & 37.1311 & 129.6 & - \\
\hline Aniline point $\left({ }^{\circ} \mathrm{F}\right)$ & 156.2 & 184.5 & - & - \\
\hline Diesel index & 53.9527 & 68.56060 & 1.6 & 5.8 \\
\hline Viscosity $(\mathrm{cSt})$ & 3.7215 & 3.67130 & 60 & - \\
\hline Flash point $\left({ }^{\circ} \mathrm{C}\right)$ & 73 & 69 &
\end{tabular}


a)

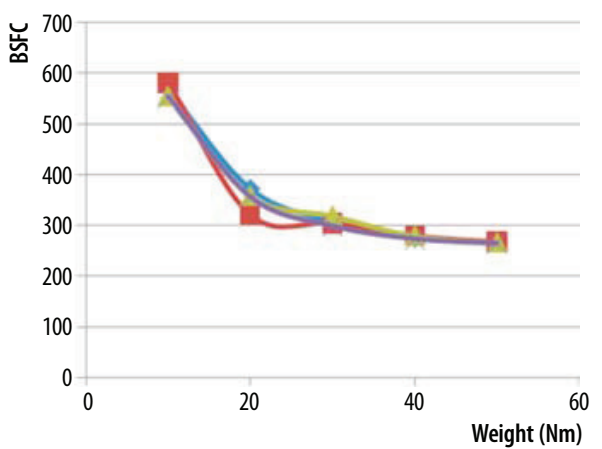

c)

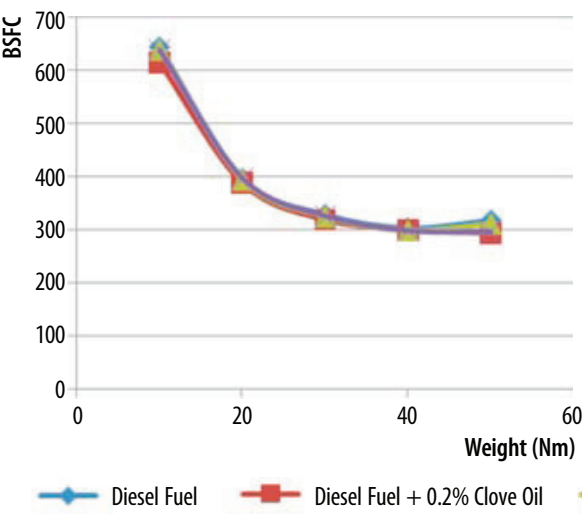

b)

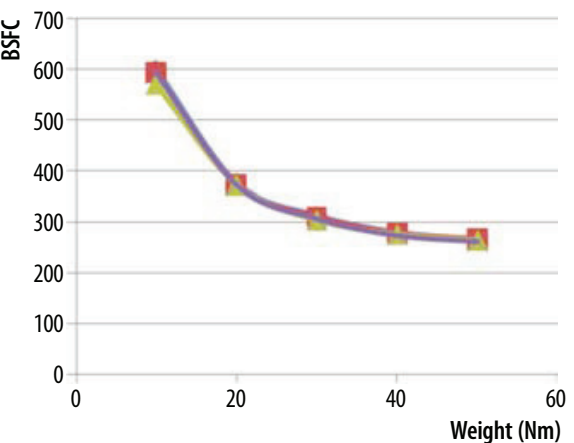

d)

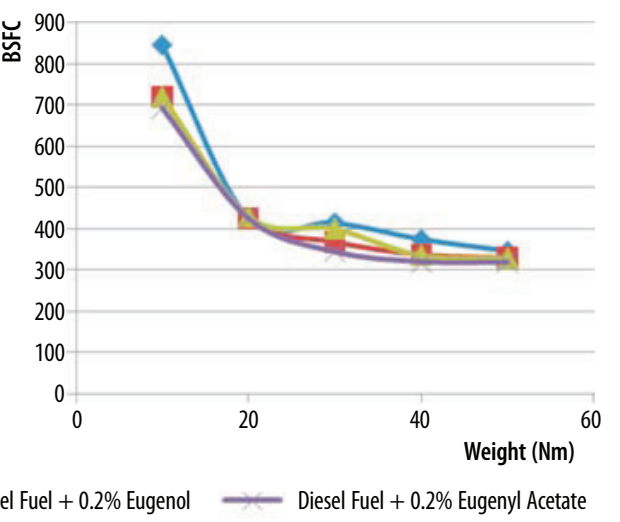

Fig. 17. BSFC of diesel fuel, diesel fuel $+0.2 \%$ clove oil, diesel fuel $+0.2 \%$ eugenol and diesel fuel $+0.2 \%$ eugenyl acetate at: $\mathrm{a}-1500 \mathrm{rpm}$; $-2000 \mathrm{rpm}$; $-2500 \mathrm{rpm}$; d - $3000 \mathrm{rpm}$

a)

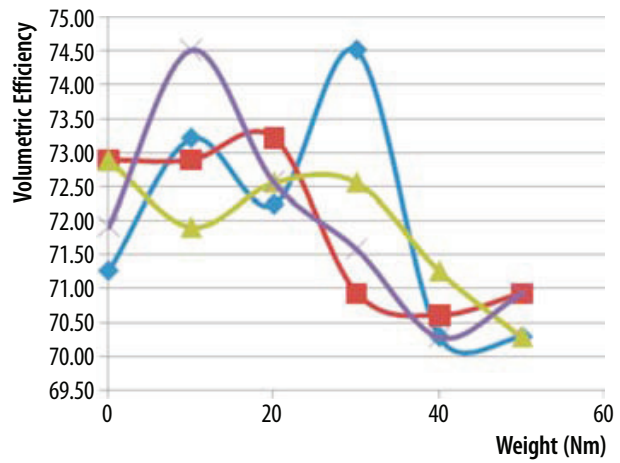

c)

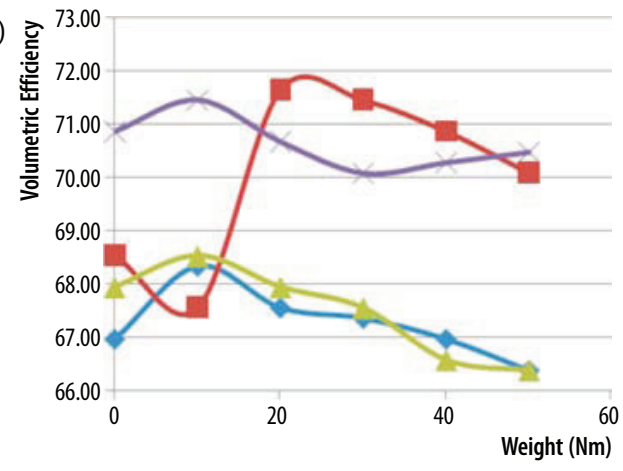

$\multimap$ Diesel Fuel b)

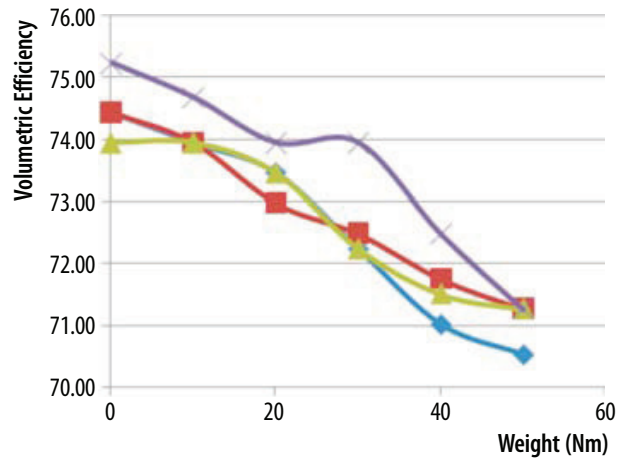

d)

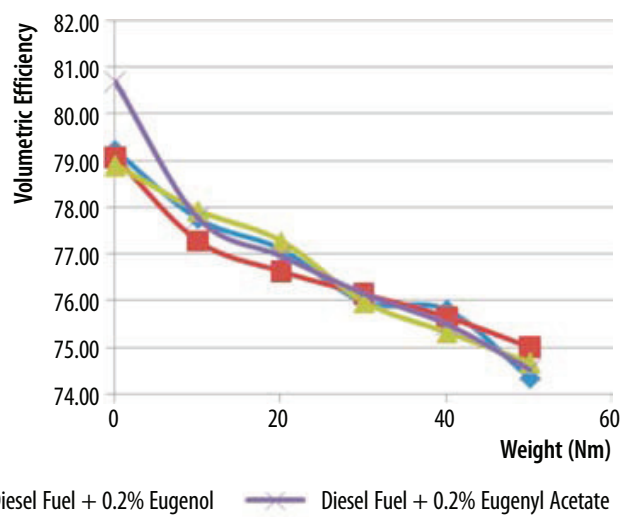

Fig. 18. Volumetric efficiency of diesel fuel, diesel fuel $+0.2 \%$ clove oil, diesel fuel $+0.2 \%$ eugenol and diesel fuel $+0.2 \%$ eugenyl acetate at: a - $1500 \mathrm{rpm}$; $-2000 \mathrm{rpm}$; $-2500 \mathrm{rpm}$; d - $3000 \mathrm{rpm}$ 
a)

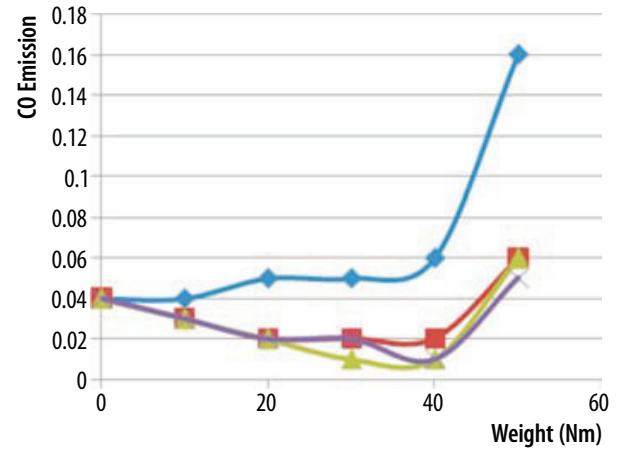

c)

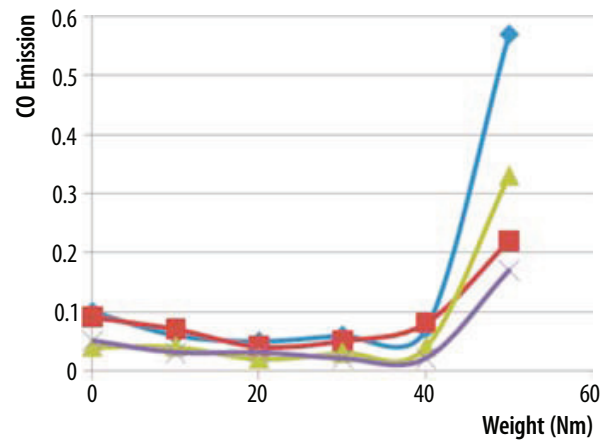

b)

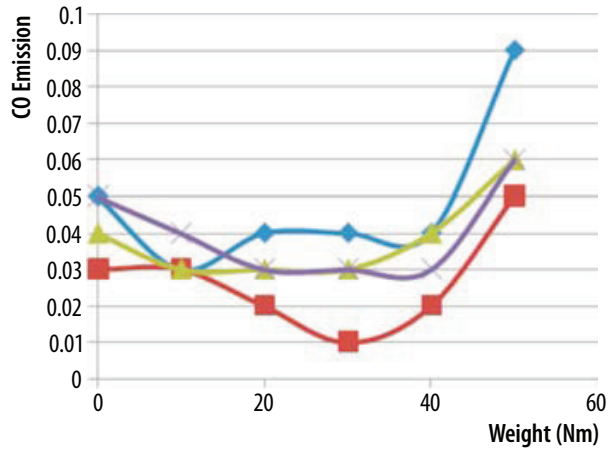

d)

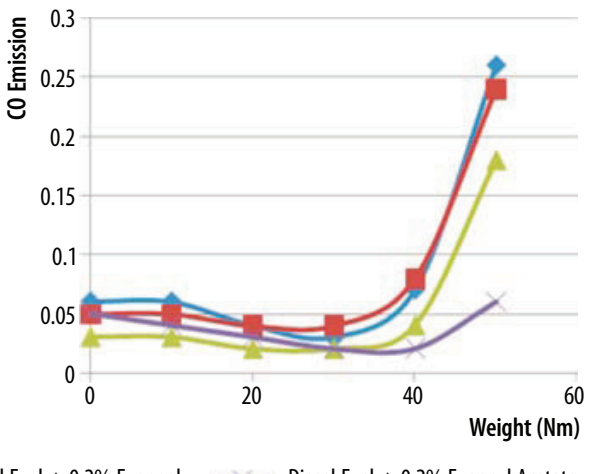

Fig. 19. CO emission of diesel fuel, diesel fuel $+0.2 \%$ clove oil, diesel fuel $+0.2 \%$ eugenol and diesel fuel+0.2\% eugenyl acetate at: a - $1500 \mathrm{rpm}$; b - $2000 \mathrm{rpm}$; - $2500 \mathrm{rpm}$; $-3000 \mathrm{rpm}$

a)

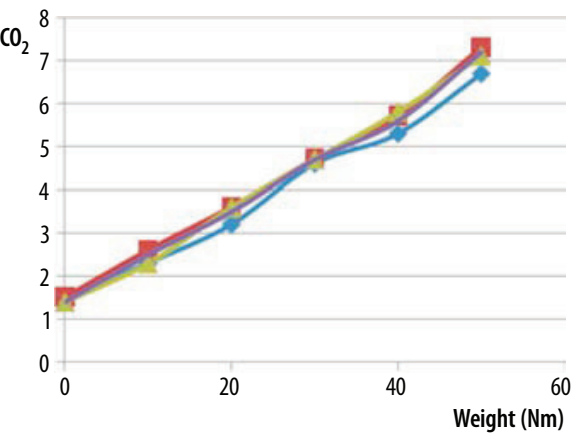

c)

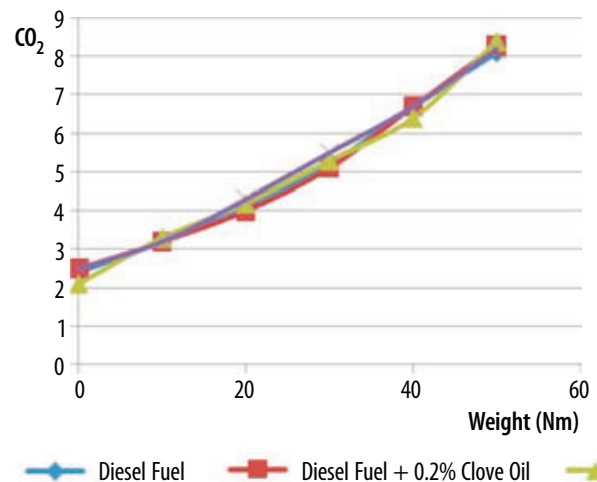

b)

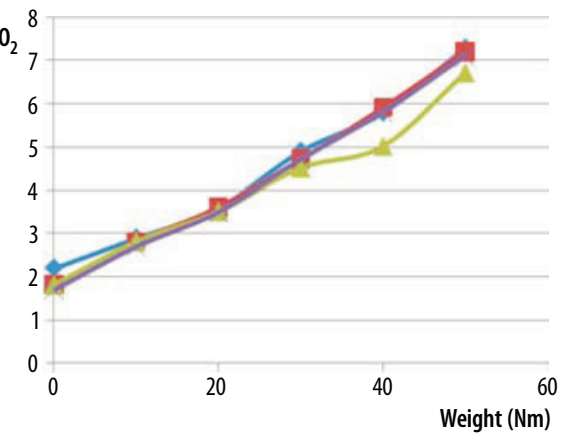

d) $\mathrm{CO}_{2} \quad{ }_{9}^{10}$

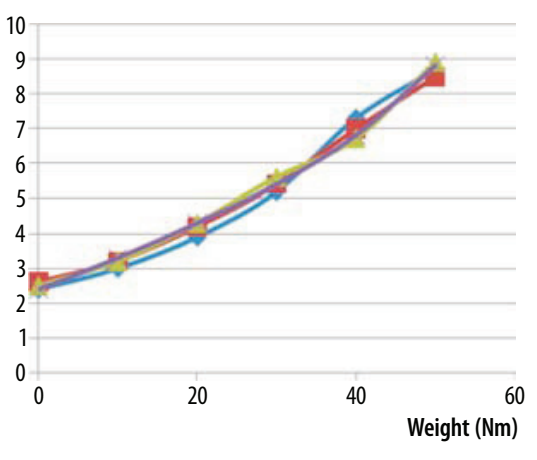

Fig. 20. $\mathrm{CO}_{2}$ emission of diesel fuel, diesel fuel $+0.2 \%$ clove oil, diesel fuel $+0.2 \%$ eugenol and diesel fuel $+0.2 \%$ eugenyl acetate at: a - $1500 \mathrm{rpm}$; b $-2000 \mathrm{rpm}$; - $2500 \mathrm{rpm}$; d - $3000 \mathrm{rpm}$ 
a)

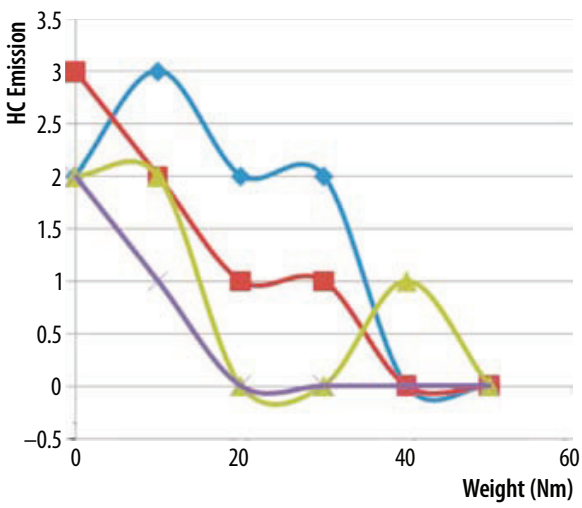

c)

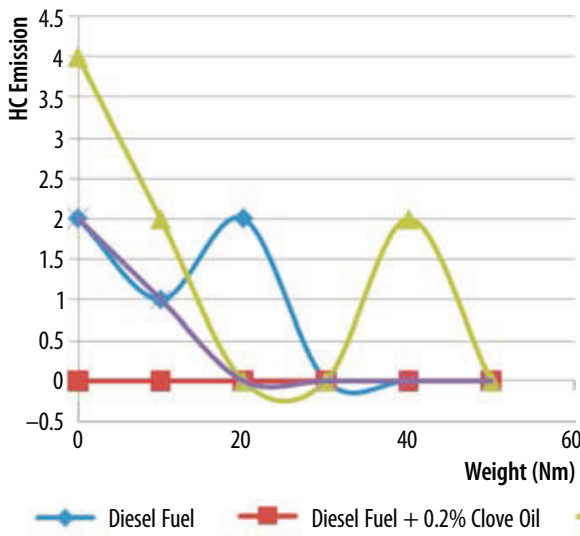

b)

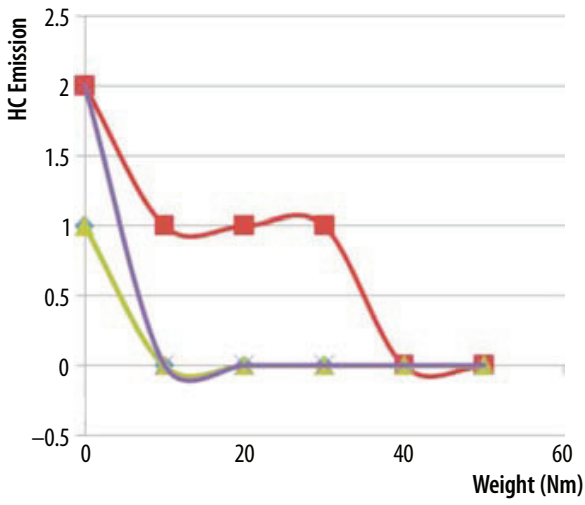

d)

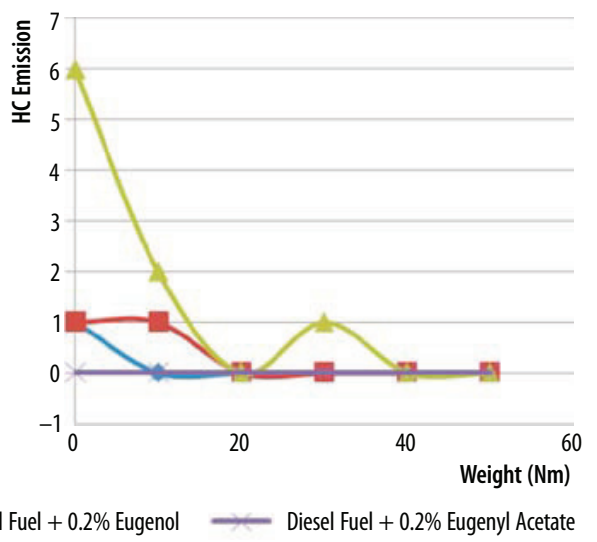

Fig. 21. HC emission of diesel fuel, diesel fuel $+0.2 \%$ clove oil, diesel fuel $+0.2 \%$ eugenol and diesel fuel $+0.2 \%$ eugenyl acetate at: a - $1500 \mathrm{rpm}$; b - $2000 \mathrm{rpm}$; $-2500 \mathrm{rpm}$; $-3000 \mathrm{rpm}$

a)

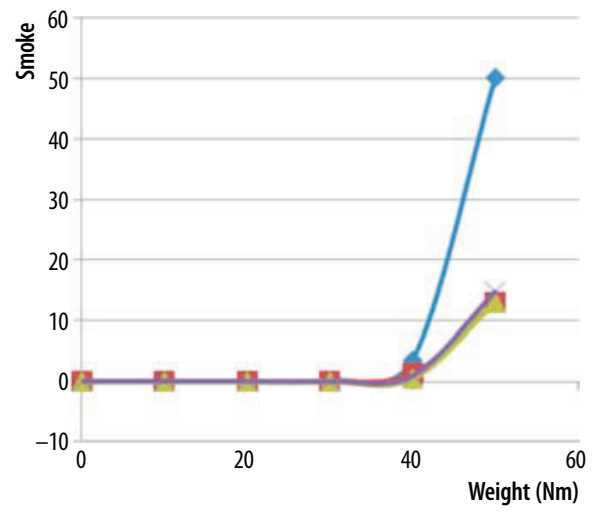

c)

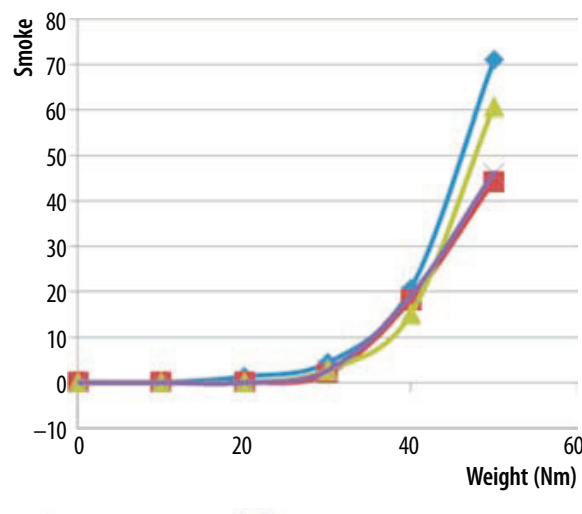

b)

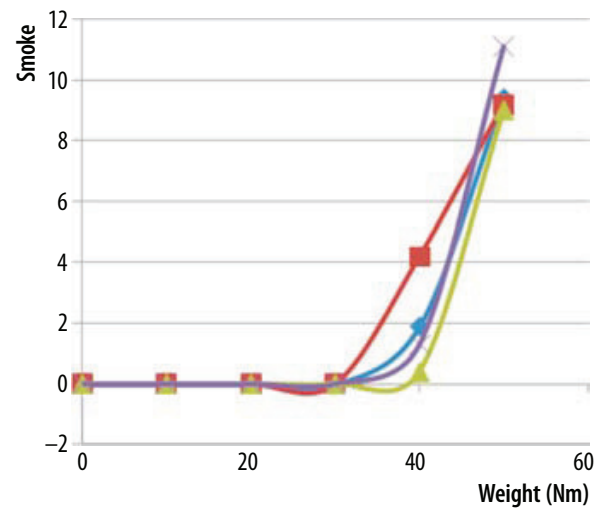

d)

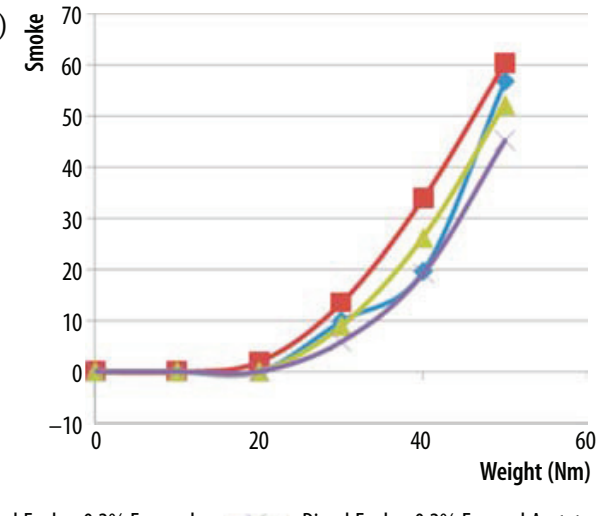

Fig. 22. Smoke emission of diesel fuel, diesel fuel $+0.2 \%$ clove oil, diesel fuel $+0.2 \%$ eugenol and diesel fuel $+0.2 \%$ eugenyl acetate at: a - $1500 \mathrm{rpm}$; b $-2000 \mathrm{rpm}$; c $-2500 \mathrm{rpm}$; $-3000 \mathrm{rpm}$ 


\section{c. Smoke (Particulates)}

At 0-20 Nm, smoke was not detected, whereas at 40-50 Nm, an increase in smoke was noticed. Generally, the reformulation of diesel fuel using bio-additives still gives a lower concentration of smoke than unreformulated diesel fuel (Fig. 22). This result is in accord with Choi

a)

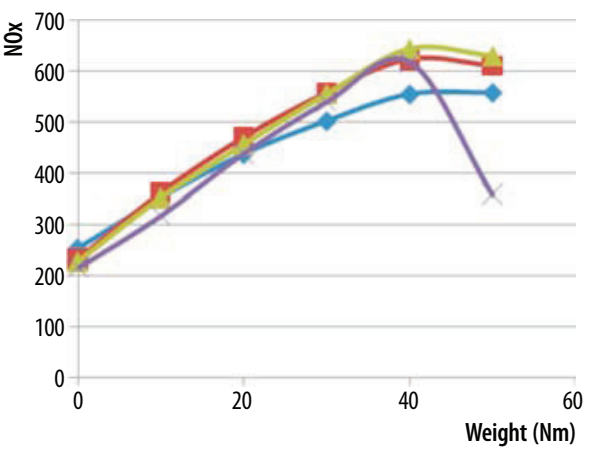

c)

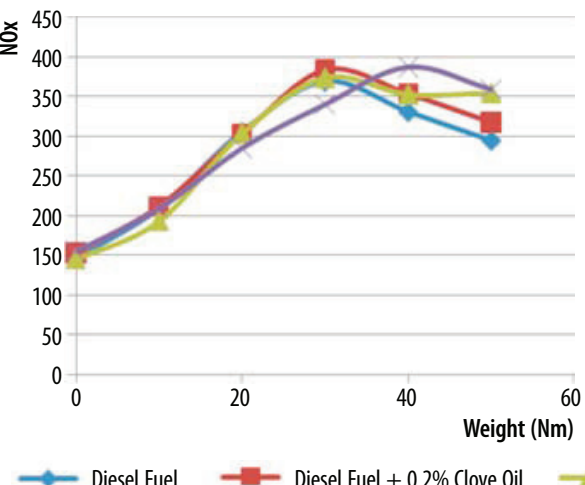

and Reitz (1999) who proposed that the oxygen atoms contained in the additive lead to oxidize particulates.

d. $N O_{x}$

If $\mathrm{CO}, \mathrm{HC}$ and smoke emission decrease, consequently, the concentration of $\mathrm{NO}_{\mathrm{x}}$ is going to increase (Fig. 23). This result is in accord with Klell theory (1998) b)

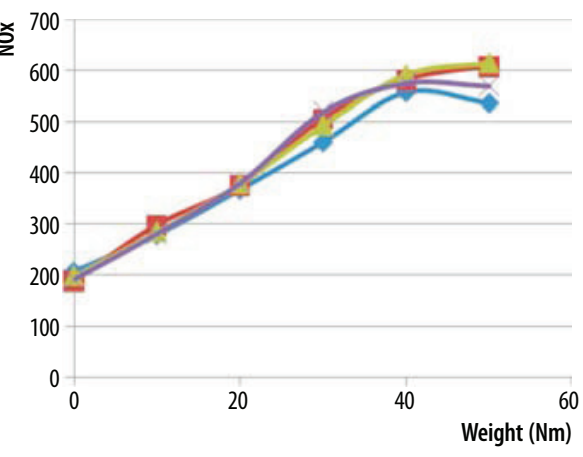

d) $\stackrel{乛}{2}$

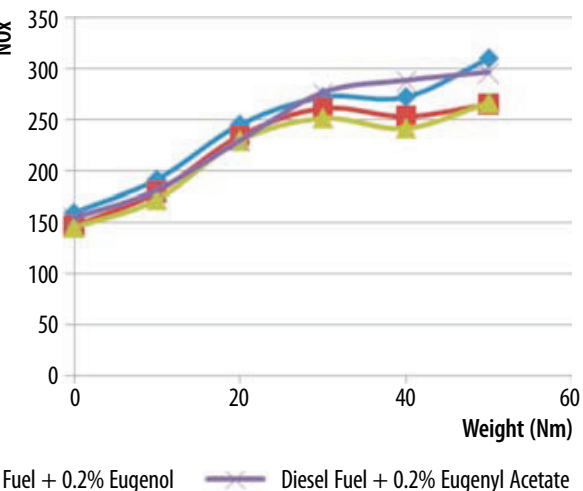

Fig. 23. $\mathrm{NO}_{\mathrm{x}}$ emission of diesel fuel, diesel fuel $+0.2 \%$ clove oil, diesel fuel $+0.2 \%$ eugenol and diesel fuel $+0.2 \%$ eugenyl acetate at: $\mathrm{a}-1500 \mathrm{rpm} ; \mathrm{b}-2000 \mathrm{rpm}$; - $2500 \mathrm{rpm}$; d $-3000 \mathrm{rpm}$

a)

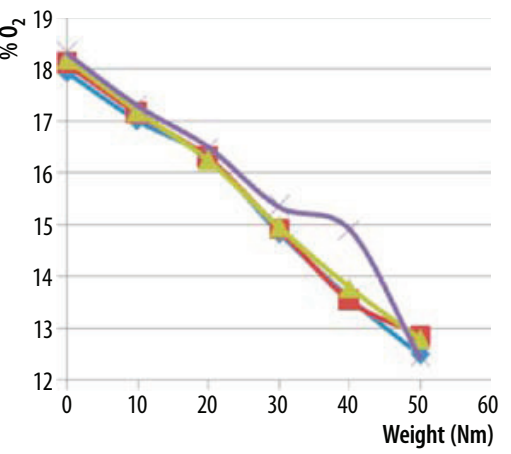

c)

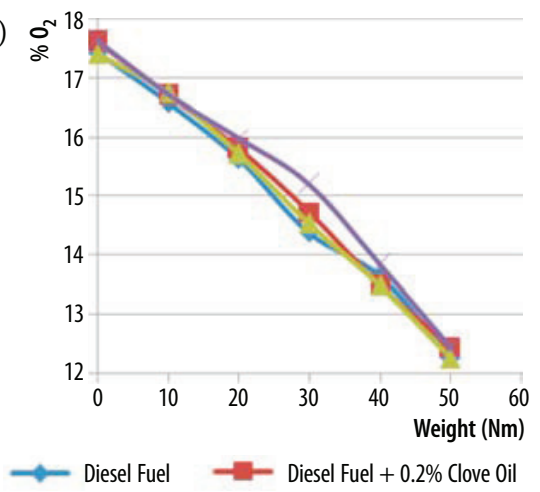

b) $\overbrace{}^{219}$

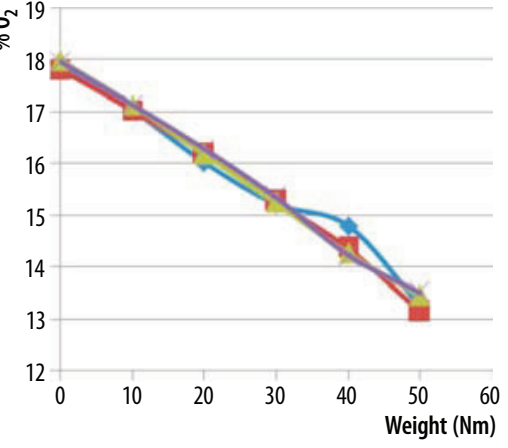

d) $\overbrace{}^{18}$

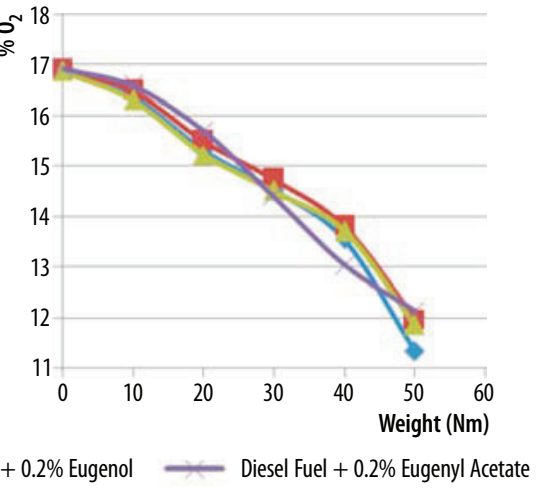

Fig. 24. The concentration of oxygen atoms in the exhaust emission of diesel fuel, diesel fuel $+0.2 \%$ clove oil, diesel fuel $+0.2 \%$ eugenol and diesel fuel $+0.2 \%$ eugenyl acetate at: $\mathrm{a}-1500 \mathrm{rpm}$; $-2000 \mathrm{rpm} ; \mathrm{c}-2500 \mathrm{rpm}$; $-3000 \mathrm{rpm}$ 
who proposed that a decrease in $\mathrm{CO}$ and $\mathrm{HC}$ emission rate would follow with an increase in $\mathrm{NO}_{\mathrm{x}}$ concentration. An increase in $\mathrm{NO}_{\mathrm{x}}$ emission is caused by the use of the air, so at high temperature, $\mathrm{N}_{2}$ and $\mathrm{O}_{2}$ can react into $\mathrm{NO}$ :

$$
\mathrm{N}_{2}+\mathrm{O}_{2} \rightarrow 2 \text { NO. }
$$

The next reaction of $\mathrm{NO}$ in the air leads to $\mathrm{NO}_{2}$. e. $\mathrm{O}_{2}$

As oxygen atoms are supplied internally, fuel blends with bio-additives lead to an increase in the high content of oxygen in exhaust emissions.

At $2500 \mathrm{rpm}$ and $3000 \mathrm{rpm}$, a high concentration of oxygen content accords with the results of the conducted experiment which has shown that at high speed, the reformulation of the bio-additives give effectiveness to the fuel combustion process (Fig. 24).

\section{Conclusions}

1. In general, clove oil, eugenol and eugenyl acetate lead to a decrease in the BSFC of diesel fuel, CO, HC and smoke emissions.

2. The oxygenated molecular structure and its high oxygen content play a significant role in the mechanism responsible for the performance of these fuel blends with bio-additives and decreasing emissions.

3. Eugenyl acetate has the best performance as a diesel fuel bio-additive which is expressed by the highest volumetric efficiency.

\section{References}

Al-Hasan, M. I.; Al-Momany, M. 2008. The effect of iso-butanol-diesel blends on engine performance, Transport 23(4): 306-310. doi:10.3846/1648-4142.2008.23.306-310

Butkus, A.; Pukalskas, S.; Bogdanovičius, Z. 2007. The influence of turpentine additive on the ecological parameters of diesel engines, Transport 22(2): 80-82.

Callahan, T. J.; Ryan, T. W. III; Dodge, L. G.; Schwalb, J. A. 1987. Effects of fuel properties on diesel spray characteristics, SAE Paper No 870533.

Chen, H.; Wang, J.; Shuai, S.; Chen, W. 2008. Study of oxygenated biomass fuel blends on a diesel engine, Fuel 87(15-16): 3462-3468. doi:10.1016/j.fuel.2008.04.034

Choi, C. Y.; Reitz, R. D. 1999. An experimental study on the effects of oxygenated fuel blends and multiple injection strategies on DI diesel engine emissions, Fuel 78(11): 1303-1317. doi:10.1016/S0016-2361(99)00058-7

Gupta, A.; Miller, D. L.; Cernansky, N. P. 2007. A detailed kinetic study on the effect of DTBP on PRF combustion in HCCI engines, SAE Paper No 2007-01-2002.

Johnson, R. 2008. A Fundamental Study of the Oxidation Behavior of SI Primary Reference Fuels with Propionaldehyde and DTBP as an Additive. A Thesis Submitted to the Faculty of Drexel University by Rodney Johnson in partial fulfillment of the requirements for the degree of Doctor of Philosophy. Available from Internet: <http://idea.library.drexel. edu/bitstream/1860/2834/1/Johnson_Rodney.pdf >. 141 p.

Kadarohman, A. 2003. Isomerisasi, Hidrogenasi Eugenol, Dan Sintesis Turunan Kariofilena. Doctoral Dissertation: Chemistry of Essential Oil, Organic Chemistry. Gadjah Mada University: Science. 180 p.

Kadarohman, A.; Hernani; Fitri, K.; Rizki, M. A. 2008. Potency of clove oil and turpentine oil as a diesel fuel bioadditives and their performance on one cylinder engine, in Proceeding of the International Seminar on Chemistry, 721.

Klell, M. 1998. Internal Combustion Engines. Austria, Technical University Graz. 71 p.

Kwanchareon, P.; Luengnaruemitchai, A.; Jai-In, S. 2007. Solubility of a diesel-biodiesel-ethanol blend, its fuel properties, and its emission characteristics from diesel engine, Fuel 86(7-8): 1053-1061. doi:10.1016/j.fuel.2006.09.034

Lebedevas, S.; Lebedeva, G. 2009. The problems of using alcohol biofuel mixtures in the Lithuanian transport system, Transport 24(1): 58-65. doi:10.3846/1648-4142.2009.24.58-65

Lebedevas, S.; Lebedeva, G.; Makarevičienè, V.; Janulis, P.; Sendzikiené, E. 2009. Usage of fuel mixtures containing ethanol and rapeseed oil methyl esters in a diesel engine, Energy \& Fuels 23(1): 217-223. doi:10.1021/ef800512z

Lebedevas, S.; Vaicekauskas, A.; Suškov, P. 2007. Presumptions of effective operation of diesel engines running on RME biodiesel. Research on kinetics of combustion of RME biodiesel, Transport 22(2): 126-133.

Lingaitis, L. P.; Pukalskas, S. 2008a. Ecological aspects of using biological diesel oil in railway transport, Transport 23(2): 138-143. doi:10.3846/1648-4142.2008.23.138-143

Lingaitis, L. P.; Pukalskas, S. 2008b. The economic effect of using biological diesel oil on railway transport, Transport 23(4): 287-290. doi:10.3846/1648-4142.2008.23.287-290

Matijošius, J. Sokolovskij, E. 2009. Research into the quality of fuels and their biocomponents, Transport 24(3): 212-217. doi:10.3846/1648-4142.2009.24.212-217

Mittelbach, M.; Remschmidt, C. 2004. Biodiesel: a Comprehensive Handbook. Graz, Austria. 330 p.

Mueller, C. J.; Martin, G. C. 2002. Effects of oxygenated compounds on combustion and soot evolution in a DI diesel engine: broadband natural luminosity imaging, SAE Paper No 2002-01-1631.

Pukalskas, S.; Bogdanovičius, Z.; Sendžikienè, E.; Makarevičiene, V.; Janulis, P. 2009. The mixture of biobutanol and petrol for Otto engines, Transport 24(4): 301-307. doi:10.3846/1648-4142.2009.24.301-307

Raslavičius, L.; Bazaras, Ž. 2009. The analysis of the motor characteristics of D-RME-E fuel blend during on-field tests, Transport 24(3): 187-191. doi:10.3846/1648-4142.2009.24.187-191

Raslavičius, L.; Markšaitis, D. 2007. Research into three-component biodiesel fuels combustion process using a single droplet technique, Transport 22(4): 312-315.

Shi, X.; Pang, X.; Mu, Y.; He, H.; Shuai, S.; Wang, J.; Chen, H.; Li, R. 2006. Emission reduction potential of using ethanolbiodiesel-diesel fuel blend on heavy-duty diesel engine, Atmospheric Environment 40(14): 2567-2574.

doi:10.1016/j.atmosenv.2005.12.026

Shih, L. K. 1998. Comparison of the effects of various fuel additives on the diesel engine emissions, SAE Paper No 982573.

Song, J.; Cheenkachorn, K.; Wang, J.; Perez, J.; Boehman, A. L.; Young, P. J.; Waller, F. J. 2002. Effect of oxygenated fuel on combustion and emissions in a light-duty turbo diesel engine, Energy Fuels 16(2): 294-301. doi:10.1021/ef010167t

Török, Á. 2009. Theoretical estimation of the environmental impact of biofuel mixtures, Transport 24(1): 26-29. doi:10.3846/1648-4142.2009.24.26-29

Yao, C. D.; Zhang, Z. H.; Xu, Y. L.; Huang, Y. 2008. Experimental investigation of effects of bio-additives on fuel economy of the gasoline engine, Science in China Series E: Technological Sciences 51(8): 1177-1185. doi:10.1007/s11431-008-0170-1 